\title{
A Stronghold of Routine Corporatism? : The Involvement of Interest Groups in Policy Making in Finland
}

\section{Vesa, Juho Antti}

2018-12

Vesa , J A , Kantola , A \& Binderkrantz , A S 2018 , ' A Stronghold of Routine Corporatism?

The Involvement of Interest Groups in Policy Making in Finland ', Scandinavian Political

Studies , vol. 41 , no. 4 , pp. 239-262 . https://doi.org/10.1111/1467-9477.12128

http://hdl.handle.net/10138/323945

https://doi.org/10.1111/1467-9477.12128

cc_by_nc_nd

acceptedVersion

Downloaded from Helda, University of Helsinki institutional repository.

This is an electronic reprint of the original article.

This reprint may differ from the original in pagination and typographic detail.

Please cite the original version. 


\title{
Authors' accepted version
}

Vesa, J., Kantola, A. and Binderkrantz, A.S. (2018), A Stronghold of Routine Corporatism? The Involvement of Interest Groups in Policy Making in Finland. Scandinavian Political Studies, 41: 239-262. doi:10.1111/1467-9477.12128

\section{A Stronghold of Routine Corporatism? The Involvement of Interest Groups in Policymaking in Finland}

\begin{abstract}
While the Nordic countries have a tradition of integrating privileged interest groups into policymaking, a number of studies have argued that this Nordic 'routine corporatism' has changed over the last decades. Studies of Denmark, Norway and Sweden demonstrate that interest groups are less frequently involved in committees preparing policy, that lobbying of parliament has become more important and that the position of citizen groups has strengthened. However, systematic studies of present-day Finland are largely missing. This paper therefore adds to the literature by focusing on the Finnish case. Drawing on surveys of interest groups and civil servants, we assess the involvement of interest groups in policymaking in Finland and compare Finland with Denmark and the UK. We find that (1) working groups and similar bodies are still very important sites of advocacy; (2) public administration is a more important site of advocacy than parliament or government; (3) economic groups continue to enjoy a particularly privileged position; and (4) resources predict groups' access to policymaking more strongly in Finland than in Denmark or the UK. These findings imply that routine corporatism persists in Finland to a greater extent than in Denmark. The study augments the existing evidence that corporatism may have adapted to new circumstances rather than being eliminated.
\end{abstract}




\section{Introduction}

The Nordic countries have a long tradition of tight integration of interest groups into policymaking, particularly through their membership on various committees, boards and councils (e.g. Helander 1979; Christiansen \& Rommetvedt 1999; Pallesen 2006; Christiansen et al. 2010; Öberg et al. 2011). In particular, economic interest organizations - trade unions, business associations and organizations of public service providers-have enjoyed privileged access to committees (see Christiansen 2017). This has typically been discussed as an aspect of corporatism, which has in the Nordic literature often been understood as the institutionalized integration of interest groups in policy preparation and implementation (Blom-Hansen 2000; Christiansen et al. 2010; Öberg et al. 2011). Here, we term this aspect of corporatism 'routine corporatism', distinguishing it from 'peak corporatism', which refers to tripartite income policy bargaining and related social pacts (Arter 2006, 110-117).

Since the 1990s, a number of studies have documented change in this 'Nordic model' of interest group involvement. Committees with interest groups are less frequently used to prepare policies (e.g. Christiansen et al. 2010; Öberg et al. 2011), and parliaments have become more important as sites of lobbying (Christiansen \& Rommetvedt 1999; Binderkrantz 2003; Rommetvedt et al. 2013). At the same time, there are signs that some key traits of the traditional Nordic model persist (Binderkrantz \& Christiansen 2015, 1023). In particular, committees are still commonly used in Denmark, Norway and Sweden, and-although citizen groups have increased their representationeconomic interest groups seem to have retained particularly privileged access to policymaking (e.g. Binderkrantz \& Christiansen 2015; Christiansen 2017). 
While there is evidence of adaptation of routine corporatism to new circumstances in most Nordic countries, less is known regarding Finland. There, peak corporatism has long been the most politically visible aspect of corporatism, and there are only a few studies about routine corporatism (cf. Helander 1979; Helander \& Johansson 1998). Some studies indicate the committee system has become less institutionalized and centralized as ministerial working groups have largely replaced the governmentappointed committees (see Temmes 2001; Rainio-Niemi 2010; Slant \& Rantala 2013). A few studies also argue that corporatism persists in specific policy sectors, such as the environmental (Gronow \& Ylä-Anttila 2016) and innovation policy sectors (Ornston 2013). Based on existing evidence, however, it is not possible to assess the current strength of routine corporatism in Finland.

This article contributes to the literature on Nordic routine corporatism by focusing on the understudied case of Finland. Moreover, by comparing Finland with Denmark and the UK we increase understanding of the factors behind the alleged adaptation of corporatist practices to new circumstances. Many scholars argue that one important factor that may explain the existence and strength of corporatism is the strength of governments vis-à-vis parliaments (e.g. Binderkrantz \& Christiansen 2015; Öberg et al. 2011). Finland is interesting in this regard due to its reliance on strong, often oversized majority coalitions that deviate from the weaker types of governments typical of the other Nordic countries.

Interest group involvement in committees and similar bodies is commonly used as an indicator of routine corporatism (e.g. Christiansen et al. 2010; Öberg et al. 2011). In addition, as corporatism has been argued to reduce the role of parliament, it is relevant to compare how important extra-parliamentary policymaking is vis-à-vis the parliamentary phase (cf. Rommetvedt et al. 2013). Further, Nordic corporatism has been 
characterized by the especially privileged position of economic interest groups (e.g. Helander \& Johansson 1998; Christiansen et al. 2018), and it is interesting to see whether this still holds true in Finland. Therefore, we look at two indicators of the strength and nature of Finnish corporatism, asking (1) what are the most important sites of policy advocacy (e.g. committees, parliament) for interest groups and (2) what kinds of groups have privileged access to policymaking. To answer these questions, we employ a novel dataset based on surveys of interest groups and civil servants. By drawing on comparable interest group surveys conducted in Denmark and the UK, we compare Finland with another Nordic country traditionally classified as corporatist and with the UK, a prime example of a pluralist system (Siaroff 1999).

\section{Routine Corporatism: The Classic Nordic Model of Interest Group Involvement}

Corporatism takes many forms. 'Peak corporatism' refers to tripartite income policy bargaining and related 'social pacts' negotiated between employers' peak organizations, unions and the state (Arter 2006, 111). Peak corporatism has been a very important aspect of Finnish economic and social policymaking since 1968 when the first comprehensive income policy deal was struck. This article, however, focuses on what Arter terms 'routine corporatism', which refers to the institutionalized integration of privileged interest groups into the pre-parliamentary stage of policymaking and policy implementation (Arter 2006, 114; Christiansen et al. 2010, 27). Routine corporatism is not limited to tripartite bargaining and income and labour market policy but can exist in any policy sector and involve any kind of interest group (Christiansen et al. 2010, 27).

The most tangible manifestation of routine corporatism in the Nordic countries has been interest groups' membership on committees, boards, councils and the like (Christiansen et al. 2010; Öberg et al. 2011). This tradition can be traced back to the seventeenth 
century in Sweden and to the late nineteenth and early twentieth centuries in Denmark and Norway (Arter 2006, 114; Christiansen et al. 2010). In Finland, while committees date back to the time of Swedish rule, interest group membership became more common after the Second World War (Helander 1979; Helander \& Johansson 1998; Rainio-Niemi 2010, 245-246).

In the Nordic countries, economic interest groups such as trade unions and business groups have traditionally enjoyed a particularly privileged position in policymaking (e.g. Helander \& Johansson 1998, 128-138; Binderkrantz \& Christiansen 2015). In addition, another major group of economic interest groups, namely the institutional interest groups representing public or semi-public institutions, such as educational institutions or municipalities, have been well represented on committees (Christiansen 2017). In contrast, citizen groups, defined as groups representing social groups or causes not associated with the economy, have traditionally been weaker.

Looking at economic interest groups, peak and routine corporatism seem to be interrelated. Economic interest groups - particularly trade unions and employers' peak organizations - strengthened their standing in the Finnish committee system from the late 1960s onwards with the birth of the national tripartite income policy bargaining system (Helander 1979; Helander \& Johansson 1998, 128-138; Rainio-Niemi 2010). Thus, the strong role of peak labour market organizations in peak corporatism, that is, wage bargaining, was reflected in routine corporatism.

It has been argued that corporatism undermined the role of parliaments. Rokkan (1966) famously argued that in Norway, the 'corporatist channel' of interest representation was more important than the 'numerical channel' (i.e. the role of political parties and of parliament). He concluded that 'votes count, but resources decide'; resourceful interest 
groups had more power than parliamentarians. Similar views were voiced in Finland, especially in the 1970s (see Elder et al. 1988, 170).

\section{Changing Patterns of Routine Corporatism and the Understudied Case of Finland}

Since the 1990s, numerous studies have documented change in routine corporatism in Nordic countries. In this section, we review these findings and formulate expectations for the Finnish situation, highlighting our expectation that the development here may not mirror the situation in the other Nordic countries. Overall, we draw on an exchange model frequently used in the literature. The interaction between interest organizations and the state is seen as an exchange relationship, where groups obtain favourable public policies in exchange for information and support of public decisions (Binderkrantz et al. 2015; Öberg et al. 2011). Crucially, the alleged adaptation of corporatist arrangements is thus explained by a decline in the value of goods exchanged, related to factors such as electoral volatility, the power of parliaments vis-à-vis governments and mediatization (Christiansen 2017; Öberg et al. 2011).

\section{The decline of committees and similar bodies}

Studies of Denmark, Norway and Sweden have identified significant declines from the 1960 s to the 2000 s in the number of committees with interest group members (Christiansen \& Rommetvedt 1999; Christiansen et al. 2010; Öberg et al. 2011). This trend has been particular marked with regard to policy preparation. There are no equivalent systematic studies of the development of the Finnish committee system into the 2000s. However, we do know that the number of traditional government-mandated committees (komiteat) with interest group members peaked in the 1970s and has 
subsequently declined (Helander \& Johansson 1998, 132-133, 138, 141). This centralized committee system had been largely abandoned by the 2000s (Helander \& Johansson 1998; Temmes 2001; Rainio-Niemi 2010). In 2012, committees or commissions (toimikunta) were used in only $1 \%$ of law preparation processes (Slant \& Rantala 2013, 20). At the same time, lobbyism in the form of direct contact with policymakers has been a rising trend in political advocacy (Kantola 2016).

The demise of the committee system has been taken to indicate the decline of routine corporatism (e.g. see Ruostetsaari 2015, 202). However, this decline should not be overstated. While the traditional committees mandated by the government are now used only very rarely, working groups mandated by ministries are still used in policy preparation (Slant \& Rantala 2013, 20). The number of such working groups rose sharply as the number of committees declined (e.g. Temmes 2001). There are also various consultative councils and boards (e.g. the Economic Council). However, while we know that current working groups may include interest groups (Vehka 2015), we know little about how many working groups include interest groups or, more significantly, the importance of these working groups as sites of advocacy for interest groups (cf. Lundberg 2015).

We expect that routine corporatism has been more resilient in Finland than in the other Nordic countries and that this means that committees, working groups and the like are especially important for Finnish interest groups. There are three reasons to expect this. First, Öberg et al. $(2011,391)$ argue that corporatism has declined in other Nordic countries because of the decreasing ability of governments to engage with interest groups due to growing political fragmentation and more assertive opposition. In Finland, however, an opposite trend has occurred. Beginning in the 1980s, 'Finland became a strongly executive-dominated polity', where 'oversized coalitions $[\ldots]$ have 
ruled without much effective opposition from the Eduskunta [parliament]' (Raunio 2011, 125, 139). This contrasts with other Nordic countries, where minority governments must negotiate continuously with opposition parties (Christiansen \& Damgaard 2008; Öberg et al. 2011). Therefore, governments in Finland are usually stronger and have the 'capacity to control what interest groups want in return in corporatist exchange' (Öberg et al. 2011, 378).

Second, the Finnish government type may strengthen corporatism through another, more mundane mechanism. Christiansen $(2017,41-42)$ points out that time-consuming committee work fits poorly in today's 'fast and mediatized policy processes' (Christiansen 2017, 41). In Finland, there has also been critical public discussion of the fast pace of policymaking, and one reason for the abolition of the committee system was to increase the cost-effectiveness of policymaking (Arter 2006; Temmes 2001). However, policymaking in the Finnish majority governments has been quite stable. Reforms are typically already agreed upon when a government is formed, and policymaking largely follows the government programme. The government has almost four years to prepare most policies; therefore, there might be more time and room for working groups and the like. In contrast, in the minority coalitions typical of the other Nordic countries, policy processes are often shorter and more politicized, as these governments engage continuously in negotiations with opposition parties (Christiansen \& Damgaard 2008).

Third, differences in economic history lead us to expect that routine corporatism might be more resilient in Finland. Scholars have argued that one reason for decreased corporatism in other Nordic countries is that welfare retrenchment and austerity politics have become more common, and governments may wish to keep interest groups at arm's length during retrenchment (Öberg et al. 2011; Christiansen 2017, 41-42). 
However, this argument does not apply equally to Finland. While corporatism has been a 'fair weather phenomenon' in other Nordic countries, it has been seen as more of a 'foul weather phenomenon' in Finland because it had its 'origins' and 'greatest significance' during the economic downturns of the late 1960s and the late 1990s (Arter $2006,114) .{ }^{1}$ For instance, during the economic recession of the 1990 s, a strong ethos of consensus seeking emerged among the political elite (Kantola \& Kananen 2013). Based on the logic of sacrificing short-term self-interests for the long-term 'common good', this echoed earlier occasions in Finnish history when the nation was unified against external threats, such as in the 'spirit of the Winter War'.

\section{The declining importance of parliament as a site of advocacy}

The decline in routine corporatism has given way to less institutionalized interaction between policymakers and interest groups; lobbying has become a more important advocacy strategy (Christiansen \& Rommetvedt 1999; Binderkrantz 2003; Rommetvedt et al. 2013). Studies in Denmark and Norway show that as committee membership has become less effective as a means of influencing policymaking, interest groups increasingly lobby members of parliament and ministers (Christiansen \& Rommetvedt 1999; Binderkrantz 2003; Rommetvedt et al. 2013). This trend is reinforced by a development whereby the Danish and Norwegian parliaments have been strengthened due to increased resources and the prevalence of minority governments (Rommetvedt et al. 2013).

Again, we believe these arguments do not apply equally well to Finland and therefore that parliament is a less important advocacy site in Finland than in other Nordic countries. First, this follows logically from our expectation that routine corporatism is particularly strong in Finland. Interest groups can influence policies through their 
integration into pre-parliamentary policymaking, and the parliamentary phase is therefore arguably less important for them. Second, because political power is strongly concentrated in the executive (e.g. Raunio 2011), the parliament is probably generally less important as a site of advocacy and lobbying.

We further expect that inside the executive, the public administration is an especially important advocacy site in Finland, while the cabinet (i.e. lobbying of ministers) is less important. This is because the typically heterogeneous majority coalitions commonly stick to the programme negotiated at the beginning of their term. Major interest groups in particular may seek to affect government programmes at the time of their adoption by lobbying the party leadership, but because there are often multiple parties in government, it is hard to change the programmes later. This means that the government agenda is relatively fixed, probably making the lobbying of ministers less effective than in other Nordic countries, where the number of government parties is often lower, governments are commonly ideologically more homogeneous and policymaking is more volatile. Civil servants, in contrast, can be expected to be important targets of lobbying in Finland, because they have a central role in the implementation of the government programmes and as agenda-setters influencing the content of the programmes.

\section{Changing patterns of interest group access}

Longitudinal studies of interest group access to policymaking have been systematically conducted in Denmark, but similar studies on Finland are missing. In Denmark, citizen groups are generally better represented on committees in the 2010 s than they were in the 1970s, reflecting the emergence of new political issues, increased electoral volatility and the mediatization of politics (Binderkrantz \& Christiansen 2015). However, despite 
the rise of citizen groups, economic groups still clearly enjoy an especially privileged position (Binderkrantz et al. 2015). Among these groups, power has shifted somewhat towards business associations, while the position of trade unions has declined. Despite this, the status of unions remains strong in Denmark compared, for instance, to the UK (e.g. Binderkrantz et al. 2015; Rasmussen 2015).

Regarding Finland, there is some evidence that economic groups dominate in the 2010s (e.g. Vehka 2015; Seo 2017, 132). However, comparative studies are needed, as economic groups are strong in many democracies (e.g. Dür \& Mateo 2016). Yet it might be expected that the degree of this dominance would be higher in traditionally corporatist countries such as Finland than in pluralist countries such as the UK (cf. Christiansen et al. 2018, 4). The expected dominance of economic groups might be explained by path dependency and administrative routines, as strong bonds between civil servants and interest groups emerge over time and may be hard to break even if 'rational' from a pure resource-exchange perspective (Braun 2013). These path dependencies are arguably stronger and more difficult to break in corporatist systems, where the integration of privileged interest groups has been institutionalized. Additionally, economic groups may continue to dominate access to routine policymaking because tripartite corporatism has been more resilient in Finland (and Denmark) than, for instance, in Sweden (e.g. Anthonsen \& Lindvall 2009; Arter 2006). This may be because Finnish governments have long been more ideologically diverse, and in the absence of a bloc model of political competition, interest organizations cannot bypass bargaining with other interest groups by seeking to directly influence their ideologically allied parties in government (Anthonsen \& Lindvall 2009).

We also expect that the legacy of corporatism is reflected in how resources determine interest groups' access to policymaking in Finland. Corporatism both 'presupposes 
strong interest groups' and 'produces strong interest groups' (Christiansen 2017; Lijphart 2012). Because they seek the broadest possible political support, governments in corporatist systems have an incentive to negotiate with strong groups that broadly represent societal interests. Therefore, governments in corporatist systems have heavily subsidized interest groups (Christiansen 2012; cf. also Kantola \& Seeck 2011), and groups have an incentive to build hierarchical structures where resourceful umbrella organizations represent broad constituencies. Therefore, we would expect to find a particularly wide gap (in terms of access) between the stronger groups-which get most access and have significant resources - and weaker groups in corporatist systems. This means that we also expect groups' resources to strongly predict access to policymaking in Finland - more strongly, for instance, than in the pluralist UK.

\section{Data and Methods}

To analyse the importance of different advocacy sites and the patterns of privileged access for Finnish interest groups, we rely on surveys of groups and civil servants. Previous studies have examined both observational data on interest group activity and representation (for example in committees) and group answers to questions about strategies, privileged access and influence in surveys (Binderkrantz et al. 2015; Binderkrantz \& Christiansen 2015; Rasmussen 2015; Öberg et al. 2011). For our purposes, surveys are more suitable because they allow comparing the relevance of different arenas as seen from the group perspective. Further, surveys allow the inclusion of a wide range of groups that can report on their experience across the set of policy areas they are involved in. Moreover, surveys make it possible to study informal advocacy strategies (cf. Christiansen et al 2010, 29). However, by relying on self- 
reported activity, there is a risk of either over- or underreporting by groups, although this is probably less severe here than in studies on interest group influence (see the discussion in Binderkrantz \& Rasmussen 2015).

The inclusion of surveys of both interest groups and civil servants allows us to assess the relationship between interest groups and the bureaucracy from both sides. A survey of interest groups was conducted in Finland in 2015-2016. Our sample was intended to cover all nationwide interest groups (mostly associations with members or supporters), and we searched many sources to find groups (cf. Christiansen 2012), including online group lists (e.g. members of umbrella groups), consultation responses, newspapers and parliamentary committee hearings. We also used systematic keyword-driven Google searches. The survey was sent to 3,271 groups whose e-mail addresses we found; of these, 1,794 responded to our survey. When we limit our analyses to Finnish groups (see Table 2), we analyze the responses of 1,101 groups that reported they were both politically active and nationwide.

We compare Finland with Denmark and the UK by analysing similar surveys from Denmark (2011) and the UK (2013). The comparative analyses thus combine a mostsimilar-systems design and a most-different-systems designs. Denmark was traditionally a prime example of the Nordic model of interest group integration, although this system has subsequently changed (e.g. Christiansen et al. 2010; Rommetvedt et al. 2013; Binderkrantz \& Christiansen 2015). In the UK, corporatism has been largely absent, and the interest group system can therefore be described as pluralist (Siaroff 1999; Lijphart 2012). Although we do not use a longitudinal research design, this comparative design allows us to assess whether the current situation in Finland resembles that in another Nordic country where the Nordic model has been under pressure. It also allows a comparison with the pluralist UK, providing an indication of the extent to which 
national policy styles may have converged (cf. Richardson 1982) to the point where we can no longer talk of a distinct Nordic model of interest group involvement.

To compare Finland with Denmark and the UK, sampling was done in a similar way in each country based on observed group activity and access. We identified groups based on, for instance, responses to consultations and media appearances (see Note $\mathrm{A}$ in the Supplementary material for details). The decision to focus on the population with observed activity was made to enable comparison to the UK where the survey was only sent to these interest groups. While the level of activity may be higher for these groups than for groups not in the sample, the samples are still suitable to compare across countries and different advocacy sites. We also preformed robustness checks by comparing Finland and Denmark with a broader sample. ${ }^{2}$ Response rates for the comparative samples were $66 \%$ for Finland $(\mathrm{N}=582), 69 \%$ for Denmark $(\mathrm{N}=610)$ and $26 \%$ for the UK $(\mathrm{N}=477)$.

The groups were coded into two broad categories and seven subtypes. The category economic groups included trade unions, business associations, institutional groups (representing public or semi-public institutions) and professional associations. Citizen groups $^{3}$ were divided into identity groups (e.g. patients, the elderly), leisure groups and public interest groups (e.g. environmental, humanitarian) (cf. Binderkrantz \& Christiansen 2015; Christiansen et al. 2018). As a reliability test, a random sample of 100 groups from each country was coded by another researcher. Cohen's kappa values for the group types were 0.83 for Finland, 0.91 for Denmark and 0.76 for the UK.

The survey of civil servants was conducted in Finland in 2015-2016, targeting all civil servants involved in the drafting of legislation within ministries. Because there was no existing list of the civil servants involved in law making, we sent the questionnaire to 
over 2,600 civil servants, asking that only those involved in law making should respond. In total, 256 civil servants responded. Using similar criteria, the Legislative Policy Committee found that approximately 650 civil servants were involved in law making in 2014, which indicates that about $39 \%$ of civil servants belonging to the target population responded to our survey (for representativeness, see supplementary Table A).

To assess the importance of various advocacy sites, we use descriptive statistics from the interest group survey (Table 1). Descriptive statistics enable comparison of the importance of different advocacy sites both within each country and between countries. However, we also need more rigorous testing, as the descriptive results may simply reflect the differences in group populations, for instance, regarding the overall share of different group types that may prefer different advocacy sites (cf. Rasmussen 2015; Dür \& Mateo 2016). Therefore, to control for differences in group populations, we also perform binary logistic regressions as robustness checks (supplementary Table B), where we control for various factors that may affect groups' preference for advocacy sites, such as group types, number of staff involved in political advocacy ${ }^{4}$, importance of policy influence as a goal and range of areas in which groups are active (cf. Binderkrantz 2005; see Supplementary Table D). We use logistic regression here because the dependent variables measure the importance of advocacy strategies on categorical scales (see wording in Table 1).

To analyse interest group access to policymaking, we use linear (OLS) regression analysis, with two dependent variables and two different subsets of data. First, for analyses confined to Finnish groups (Table 2), the dependent variable is an index of group satisfaction with access to policymaking. This variable is the mean of responses to questions asking whether groups are satisfied with the extent of their invitations to 
respond to consultations, to serve as members of working groups and to give evidence to parliamentary committees (see wording in supplementary Note B). The main independent variables are group types. Second, when comparing the three countries in terms of access (supplementary Table E), the dependent variable is privileged position in administrative policymaking (Binderkrantz 2005). It is a mean of responses to questions asking how often the group is, for instance, contacted by civil servants or represented in a committee (or a similar body) (see details in supplementary Note B). The main independent variables are group category and the interactions between countries and the group category and between the number of staff involved in advocacy. The interactions allow assessment of the expectations that economic groups are stronger in corporatist countries and that resources predict access most strongly in Finland. In both analyses, we included some control variables used in earlier research (e.g. Binderkrantz 2005; Dür \& Mateo 2016; see supplementary Tables C and D).

Because self-reported measures may give an incomplete picture of groups' access, we provide further insight into patterns of access by also drawing on the survey of civil servants. We surveyed Finnish civil servants (Table 3), asking them to name a recent law preparation process in which they had been involved and to name the five extragovernmental organizations with which they had interacted most during that process, beyond formal hearing practices. This provided a measure of group access to policy preparation through informal contacts with civil servants. We compare the results with those from roughly comparable studies of access in Denmark and the UK (Binderkrantz et al. 2014; Binderkrantz et al. 2015; Rasmussen 2015).

A final question concerns whether the research questions could be answered simply by looking at legal obligations of policy consultation in each country and to what extent such obligations may explain the importance of advocacy sites and patterns of access. 
While legal obligations are indeed part of the 'routine corporatism' phenomenon, the interaction between interest groups and policymakers is only marginally governed by legal requirements. Apart from a handful of legal obligations to consult specific organizations when preparing certain policies ${ }^{5}$, there are no legal requirements in the three countries regarding the targets and means of consultations (OECD 2010a, 76; OECD 2010b, 63, 2010c, 79).

\section{Results}

\section{Importance of different advocacy sites}

Table 1 presents interest group responses to the question on the importance of different tactics in their political work that sought to assess the importance of working groups, boards, councils and the like and other advocacy sites for different interest groups. In line with our expectations, for Finnish interest groups, membership on boards, councils, working groups and the like is very important (Table 1). Four out of five (81\%) Finnish groups reported that such memberships are, for them, an important or very important advocacy strategy. These extra-parliamentary bodies are important to a larger percentage of interest groups than contacts with ministers, political parties, MPs or parliamentary committees. Interestingly, direct contacts with civil servants are important to an even higher proportion of interest groups (87\%). Along with participation in working groups and the like, such contacts may be an important part of corporatist policy work, as informal corporatism often supplements formal corporatism (see Christiansen et al. 2010, 29). However, this may also indicate that lobbying is important, perhaps due to the demise of the centralized and institutionalized committee system. 
Our survey of Finnish civil servants confirms that working groups are among the most commonly used forms of consultation in law making. Roughly three out of four (73\%) of the surveyed civil servants responded that broad-based working groups, which include organizations from outside the state administration, are used in 'quite a lot' or 'all' of Finland's law-making processes (results not shown).

[Table 1 about here]

As expected, working groups and similar bodies are more important in Finland than in either Denmark or the UK (Table 1). While $81 \%$ of Finnish interest groups report that membership in working groups or similar bodies is 'important' or 'very important', the figure is $72 \%$ in Denmark and only $59 \%$ in the UK. As might be expected, these bodies are least important in the pluralist UK, where routine corporatism has traditionally been less common. Interestingly, working groups and similar extra-parliamentary bodies are also significantly more important for Finnish than Danish interest groups, even after controlling for various factors (supplementary Table B).

We also expected that public administration in general would be particularly important as an advocacy site for Finnish interest groups, and the results confirm this expectation. In Finland, interest groups perceive all strategies targeting public administration as more important than those targeting the government and parliament (Table 1). As mentioned, contacts with public servants are important or very important to a large proportion (87\%) of Finnish interest groups and are more important than contacts with ministers $(77 \%)$ or MPs (72\%). Similarly, membership in extra-parliamentary working groups or similar bodies is important to more interest groups $(81 \%)$ than contacts with parliamentary committees (72\%). Interestingly, contacts with political parties' leading politicians are among the least important tactics in Finland (73\%). While this finding is 
consistent with our expectation regarding the weakness of the parliament in Finland, party leaders should be important targets of lobbying during the preparation of the government programmes. This finding may indicate that the role of government programmes in Finnish policymaking is weaker than we expected; thus, contrary to our assumption, the role of government programmes probably does not explain why the administration is a more important target for lobbying than the cabinet.

The findings regarding Finland contrast with the situation in Denmark and the UK, where contacts with ministers are more important than contacts with civil servants (Table 1). Additionally, contacts with parliamentary committees were seen in both countries as more important than membership on extra-parliamentary committees, suggesting that administrative contacts are less important than in Finland. However, the picture is more complicated with regard to other parliamentary strategies. While parliamentary committees and contacts with party spokespersons were more important in Denmark than any administrative venue, contacts with other MPs are not very important, possibly reflecting the dominance of parties. In the UK, contacts with parliamentary committees are more important than contacts with administrative committees, but otherwise parliament is not a particularly important target for UK groups. These findings are consistent with overall system differences, as the UK parliament plays a less crucial role because of the electoral system and the high occurrence of one-party governments backed by a parliamentary majority.

Taken together, these findings confirm our expectations by showing that Finland stands out as a country where working groups and the like, as well as the public administration in general, are particularly important advocacy sites. 


\section{Patterns of interest group access}

The next question relates to patterns of interest group access to policymaking. We first look at regression models predicting groups' satisfaction with their access to policymaking among Finnish groups only (Table 2). The results show that institutional groups, business associations and trade unions are the most satisfied interest groups in Finland. Institutional groups are slightly but significantly more satisfied with their access to policymaking than business associations (our reference category), and there is no significant difference between trade unions and business associations. In Model 1, which does not include control variables, the most dissatisfied groups are leisure groups, professional associations, identity groups and public interest groups (Table 2). This supports our expectation that the economic interest groups (institutional groups, business groups and unions) that enjoyed privileged access during the heyday of corporatism in the 1970s (Helander and Johansson 1998, 136-137) also have the best access in present-day Finland. After including staff size and other control variables (Model 2), the differences between some citizen groups and business associations become smaller, suggesting that the better resources of economic groups may partially explain their more favourable position (see Figure 2).

[Table 2 about here]

The above results confirm that economic groups in Finland have a better position than citizen groups, but how do the Finnish patterns look in an international comparison? Supplementary Table E reports regression analyses with privileged position (see supplementary Note B) as the dependent variable. To compare the position of group types across the countries, the models include a dummy variable for citizen groups and for the interaction between citizen groups and countries. Contrary to our expectations, 
the difference between citizen and economic groups is slightly smaller in Finland than in either Denmark or the UK. This is indicated by the positive coefficient of the interaction 'Finland x citizen group' in Model 1 (Table E) without the control variables. When we control for staff size and other factors, however, the position of citizen groups is no longer significantly better in Finland than in Denmark, and the difference between Finland and the UK becomes smaller (Model 2), again pointing to the great importance of resources in Finland (cf. Vehka 2015).

[Figure 1 about here]

To compare the patterns of access in more detail, Figure 1 shows mean values for the variable measuring privileged position for different kinds of groups across the three countries. In Finland, public interest groups are particularly strongly positioned, while the other types of citizen groups are somewhat better represented in Denmark. The smaller difference between economic and citizen groups in Finland (Table E) seems to be caused mainly by the fact that fewer economic groups report having a privileged position in Finland than in Denmark and the UK (Figure 1). The main differences between the UK and the two Nordic countries are that professional associations are particularly well positioned in the UK, while leisure groups are relatively weak (Figure 1). Surprisingly, unions seem as privileged in the UK as in the two Nordic countries. However, as we will argue later, this may be because the surveys fail to capture the extremely high concentration of access among a handful of economic peak groups in the corporatist countries.

So far, we have looked at groups' self-reported access as measured on a four-point scale. However, this indicator tells us little about absolute levels of access, as access is often highly concentrated in the hands of a few very big and influential organizations 
(e.g. Binderkrantz \& Christiansen 2015). Therefore, it is also important to look at groups' actual contacts with policymakers. As shown earlier, informal contact with civil servants is the most important advocacy strategy for Finnish groups (Table 1), and we therefore wanted to investigate what kinds of group have access to policy preparation through informal interactions with civil servants as reported by civil servants themselves. The results resemble those of our interest group survey in the sense that economic groups receive the lion's share $(82 \%)$ of all mentions by civil servants in Finland (Table 3). What differs from the survey results, however, is the overwhelming dominance of business associations, which receive $46 \%$ of all mentions.

[Table 3 about here]

To compare absolute levels of access across the three countries, we rely on earlier studies of consultation responses and committee memberships in Denmark and the UK (Binderkrantz et al. 2014; Binderkrantz et al. 2015; Rasmussen 2015). While this allows for interesting comparisons, results should be interpreted cautiously because while the Finnish data report informal contacts, the other data sources are based on formal access. The results show that the position of economic groups is clearly stronger in both Finland and Denmark compared to the UK, which at first glance seems contrary to the results of our comparative survey as presented earlier. In Finland, $82 \%$ of civil servants' contacts were with economic groups, and in Denmark, these groups accounted for $79 \%$ of responses to written consultations and $84 \%$ of committee seats (Table 3 ). In the UK, the share of consultation responses by economic groups was much lower $(65 \%)$.

These results also suggest that trade unions in particular have a stronger position in both Finland (17\%) and Denmark (20\% and 25\%) than in the UK (4\%). This suggests that even if their position may have weakened in both Nordic countries (cf. Binderkrantz \& 
Christiansen 2015), ${ }^{6}$ unions still occupy a stronger position in these corporatist Nordic countries than in the pluralist UK (see also Christiansen 2017). However, the timing of the Finnish survey might have affected the results regarding unions to some extent. In Finland, their position has typically been stronger with the Social Democrats in the government (Raunio \& Laine 2017). Our survey of civil servants mostly covers lawmaking cases that took place under a government including the Social Democrats.

A mixed picture emerges, then, from the comparative analyses of self-reported privileged access and other indicators (Table 3) of the position of different types of groups. On one hand, the difference between citizen and economic groups is smallest in Finland with regard to self-reported access. On the other hand, economic groups clearly have a higher absolute number of contacts with policymakers in both Finland and Denmark than in the UK, and the balance between economic and citizen groups is roughly similar in Finland and Denmark (except that unions seem to be slightly stronger in Denmark).

How, then, are we to account for these seemingly contradictory findings? We believe they may reflect how access is concentrated particularly strongly among economic groups in Finland (and Denmark) due to the corporatist legacy. Indeed, in Finland, just $9 \%$ of economic groups account for half of all contacts of such groups with civil servants, indicating that access is very highly concentrated among economic groups (results not shown). In contrast, $21 \%$ of citizen groups account for half of the total contacts of citizen groups. It is also noteworthy that the 10 most often mentioned organizations in the whole data, which include mostly economic groups (with only one citizen group), account for $38 \%$ of all mentions by civil servants. This means that a handful of peak economic organizations seem to account for the lion's share of all contacts with policymakers, probably reflecting the importance of these organizations in 
corporatist countries. This high concentration of access is not captured by our survey analyses based on four-point scales.

[Figure 2 about here]

Finally, to analyse how resources affect access, we estimated the effect of the number of staff members involved in advocacy on groups' privileged position (supplementary Table E; Figure 2). As expected, we found that the size of a group's political staff predicts privileged position more strongly in Finland than in Denmark or the UK. The coefficient of the interaction term measuring the joint effect of being located in Finland and staff size is significantly higher than for Denmark or the UK (see also Figure 2).

\section{Conclusion}

This study has contributed to the literature on Nordic routine corporatism understood as the integration of organized interests into the preparation and implementation of policymaking. By comparing Finland with Denmark and the UK, we have added new empirical insights about the fate of corporatist arrangements in the Nordic countries. Although our aim has been mainly descriptive, our study also adds to the understanding of how factors such as the strength of government vis-à-vis parliament affect the importance of different advocacy sites and the patterns of privileged access to policymaking.

First, we find that although the centralized committee system has been largely abandoned, working groups, councils and similar extra-parliamentary bodies remain very important as advocacy sites for Finnish interest groups. Second, the comparison with Denmark and the UK demonstrates that the public administration is a crucial advocacy site for Finnish groups, while contacts with parliament and cabinet are 
considered more important in Denmark and the UK. Therefore, it seems that routine corporatism downplays the role of parliament in Finland, although this tendency is certainly not as pronounced as it was in the 1970s (cf. Elder et al. 1988, 170). Overall, these findings suggest that routine corporatism is stronger in Finland than in other Nordic countries.

Third, we find that economic interest groups enjoy an especially privileged position in Finland. Just like in the heyday of the committee system in the 1970s (Helander 1979, 234), economic interest groups account for an overwhelming majority of close contacts with policymakers. Here, Finland closely resembles Denmark - another country with a corporatist tradition - but differs from the pluralist UK, where citizen groups are stronger. However, among the traditionally strong tripartite actors, business organizations clearly have the upper hand nowadays, while the position of unions seems to have weakened (cf. Helander 1979, 234). Another interesting finding is the weak position of professional associations in Finland (and Denmark). A possible consequence of this may be that outside professional expertise plays a minor role in policymaking in corporatist systems.

Fourth, even if economic groups dominate in Finland, this does not mean that citizen groups are massively side-lined (e.g. see Figure 1). While we have no longitudinal data here, the present balance between economic and citizen groups appears largely similar in Denmark and Finland. Developments in Finland may mirror those in Denmark, where corporatism adapted to the increasing mobilization of citizen groups by partially integrating them in corporatist arrangements (Binderkrantz \& Christiansen 2015).

Fifth, we consistently find that groups' resources predict their access to policymaking more strongly in Finland than in the pluralist UK. This also points to a strong continuity 
in Finland, where corporatism functions as a hierarchical and monopolized system with strong interest groups at the top (cf. Lijphart 2012; Christiansen 2017).

Our findings add to recent evidence that corporatist arrangements may have adapted to changed circumstances rather than being eliminated completely (e.g. Binderkrantz \& Christiansen 2015). While it has been argued that peak corporatism persisted in Finland until the 2010s (e.g. Ruostetsaari 2015), our results suggest that also routine corporatism persists. In contrast to some recent studies (e.g. Dür \& Mateo 2016, 214), our results suggest that the distinction between corporatism and pluralism continues to be relevant in explaining interest groups' behaviour and access in Europe. Further studies are needed to assess how broadly this applies to other European countries.

\section{Acknowledgements}

This work was part of the implementation of the Finnish Government's 2014 plan for analysis, assessment and research under the 'Kaikki mukaan? Avoin hallinto ja uudet osallistumismuodot (KAMU)' project (www.tietokayttoon.fi/en), as well as supported by the the Danish Council for Independent Research under grant 903069 . We would like to thank Mika Vehka for his assistance in collecting the Finnish data, Petro Poutanen and Reijo Sund for their advice with the statistical analyses, Anne Holli for letting us to use her dataset on working group memberships, and the four anonymous reviewers for their insightful comments. 


\section{References}

Anthonsen, M. \& Lindvall, J. 2009. 'Party Competition and the Resilience of Corporatism', Government and Opposition 44(2), 167-87.

Arter, D. 2006. Democracy in Scandinavia. Consensual, Majoritarian or Mixed? Manchester: Manchester University Press.

Binderkrantz, A.S. 2003. 'Strategies of Influence: How Interest Organizations React to Changes in Parliamentary Influence and Activity', Scandinavian Political Studies 26(4), 287-306.

Binderkrantz, A.S. 2005. 'Interest Group Strategies: Navigating Between Privileged Access and Strategies of Pressure', Political Studies 53(4), 694-715.

Binderkrantz, A.S., Christiansen, P.M. \& Pedersen, H.H. 2014. 'A Privileged Position? The Influence of Business Interests in Government Consultations', Journal of Public Administration Research and Theory 24(4), 879-896.

Binderkrantz, A.S., Christiansen, P.M. \& Pedersen, H.H. 2015. 'Interest Group Access to the Bureaucracy, Parliament, and the Media', Governance 28(1), 95-112.

Binderkrantz, A.S. \& Christiansen, P.M. 2015. 'From Classic to Modern Corporatism: Interest Group Representation in Danish Public Committees in 1975 and 2010', Journal of European Public Policy 22(7), 1022-39.

Binderkrantz, A.S. \& Rasmussen, A. 2015. 'Comparing the Domestic and the EU Lobbying Context: Perceived Agenda-setting Influence in the Multi-level System of the European Union', Journal of European Public Policy 22(4), 552569. 
Blom-Hansen, J. 2000. 'Still Corporatism in Scandinavia? A Survey of Recent Empirical Findings', Scandinavian Political Studies 23(2), 157-81.

Braun, C. 2013. 'The Driving Forces of Stability. Exploring the Nature of Long-term Bureaucracy-Interest Group Interactions', Administration and Society 45(7), 809-836.

Christiansen, F.J. \& Damgaard, E. 2008. 'Parliamentary Opposition under Minority Parliamentarism: Scandinavia', The Journal of Legislative Studies 14(1-2), 4676.

Christiansen, P.M. \& Rommetvedt, H. 1999. 'From Corporatism to Lobbyism? Parliaments, Executives and Organized Interests in Denmark and Norway', Scandinavian Political Studies 22, 195-221.

Christiansen, P.M. 2012. 'The Usual Suspects: Interest Group Dynamics and Representation in Denmark', in Halpin, D. \& Jordan, G., eds., The Scale of Interest Organization in Democratic Politics. Data and Research Methods. Basingstoke: Palgrave Macmillan.

Christiansen, P.M., Nørgaard, A.S., Rommetvedt, H., Svensson, T., Thesen, G. \& Öberg, P. 2010. 'Varieties of Democracy: Interest Groups and Corporatist Committees in Scandinavian Policy Making', Voluntas 21, 22-40.

Christiansen, P.M. 2017. 'Still the Corporatist Darlings?' in Nedergaard, P. \& Wivel. A., eds., The Routledge Handbook of Scandinavian Politics. Oxon \& New York: Routledge. 
Christiansen, P.M., Mach, A. \& Varone, F. 2018. 'How Corporatist Institutions Shape the Access of Citizen Groups to Policy-Makers: Evidence from Denmark and Switzerland', Journal of European Public Policy 25(4), 526-545.

Dür, A. \& Mateo, G. 2016. Insiders versus Outsiders: Interest Group Politics in Multilevel Europe. Oxford: Oxford University Press.

Elder, N., Alastair, T.H. \& Arter, D. 1988. The Consensual Democracies? The Government and Politics of the Scandinavian States. Revised edition. New York: Basil Blackwell.

Gronow, A. \& Ylä-Anttila, T. 2016. 'Cooptation of ENGOs or Treadmill of Production? Advocacy Coalitions and Climate Change Policy in Finland', The Policy Studies Journal. doi/10.1111/psj.12185/pdf

Helander, V. 1979. 'Interest Representation in the Finnish Committee System in the Post-War Era', Scandinavian Political Studies 2(3), 221-237.

Helander, V. \& Johansson, J. 1998. Det statliga kommittéväsendet: en jämförelse mellan Sverige och Finland. Turku: Åbo Akademi.

Kantola, A. \& Kananen, J. 2013. 'Seize the Moment: Financial Crisis and the Making of the Finnish Competition State', New Political Economy 18(6), 811-826.

Kantola, A., \& Seeck, H. 2011. 'Dissemination of management into politics: Michael Porter and the political uses of management consulting', Management Learning 42(1), 25-47.

Kantola, A. 2016. 'Cleaning Rotten Politics, Selling Exclusive Liaisons: Public Relations Consultants as Storytelling Professionals between Markets and Politics', Public Relations Inquiry 5(1), 33-52. 
Lijphart, A. 2012. Patterns of Democracy: Government Forms and Performance in Thirty-six Countries. Second edition. New Haven and London: Yale University Press.

Lundberg, E. 2015. 'Injured but Not Yet Dead: A Bottom-Up Perspective on the Swedish Governmental Commissions', International Journal of Public Administration 38(5), 346-354.

OECD. 2010a. Better Regulation in Europe: Finland. Paris: OECD.

OECD. 2010b. Better Regulation in Europe: Denmark. Paris: OECD.

OECD. 2010c. Better Regulation in Europe: United Kingdom. Paris: OECD.

Ornston, D. 2013. 'Creative Corporatism: The Politics of High-Technology Competition in Nordic Europe', Comparative Political Studies, 46(6) 702-729.

Pallesen, T. 2006. 'Scandinavian Corporatism in a Trans-Atlantic Comparative Perspective', Scandinavian Political Studies 29(2), 131-145.

Rainio-Niemi, J. 2010. 'State Committees in Finland in Historical Comparative Perspective', in Alapuro, R. \& Stenius, H., eds., Nordic Associations in a European Perspective. Baden-Baden: Nomos Verlagsgesellschaft.

Rasmussen, A. 2015. Participation in Written Government Consultations in Denmark and the UK: System and Actor-level Effects. Government and Opposition 50(2), 271-299.

Raunio, T. 2011. 'Finland. Moving in the Opposite Direction', in Bergman, T. \& Strøm, K., eds., The Madisonian Turn. Political Parties and Parliamentary Democracy in Nordic Europe. Ann Arbor: University of Michigan Press. 
Raunio, T. \& Laine, N. 2017. 'Finland' in Allern, H. \& Bale, T., ed., Left-of-Centre Parties and Trade Unions in the Twenty-First Century. Oxford: Oxford University Press.

Richardson, J.J. 1982. 'Convergent Policy Styles in Europe?' in Richardson, J., ed., Policy Styles in Western Europe. London: Allen and Unwin.

Rokkan, S. 1966. 'Norway: Numerical Democracy and Corporate Pluralism', in Dahl, R.A., ed., Political Oppositions in Western Democracies. New Haven: Yale University Press.

Rommetvedt, H., Thesen, G., Christiansen, P.M. \& Nørgaard, A.S. 2013. 'Coping with Corporatism in Decline and the Revival of Parliament: Interest Group Lobbyism in Denmark and Norway, 1980-2005', Comparative Political Studies 46(4), $457-85$.

Ruostetsaari, I. 2015. Elite Recruitment and Coherence of the Inner Core of Power in Finland: Changing Patterns during the Economic Crises of 1991-2011. Lanham, MD: Lexington Books.

Seo, H. S. 2017. Reaching Out to the People? Parliament and Citizen Participation in Finland. Tampere: Tampere University Press.

Siaroff, A. 1999. 'Corporatism in 24 Industrial Democracies: Meaning and Measurement', European Journal of Political Research 36, 175-205.

Slant, O. \& Rantala, K. 2013. Vaikutusten arviointi ja lainvalmistelun perustietoja vuoden 2012 hallituksen esityksissä. Helsinki: OPTL:n tutkimustiedonantoja 122. 
Temmes, M. 2001. Määräaikaisen valmistelun kehittäminen. Helsinki: Valtiovarainministeriö.

Vehka, M. 2015. Intressiryhmien mukaan pääsy poliittisen päätöksenteon valmisteluun Suomessa. Intressiryhmäkohtaisten tekijöiden ja ympäristön vaikutuksen analyysiä. Master's thesis, University of Helsinki.

Öberg, P., Svensson, T., Christiansen, P.M., Nørgaard, A.S., Rommetvedt, H. \& Thesen, G. 2011. 'Disrupted Exchange and Declining Corporatism: Government Authority and Interest Group Capability in Scandinavia', Government and Opposition 46(3), 365-91. 


\section{Notes}

${ }^{1}$ The argument by Arter is only about peak corporatism, but we think this can be seen as an instance of a more general trait of political culture that may also explain the strength of routine corporatism.

${ }^{2}$ In Finland and Denmark, the surveys were also sent to larger, comparable samples of groups based on internet searches, etc. (see a detailed description of the Finnish sample on p. 13). All comparative analyses were done also using this broader sample (total $\mathrm{N}=$ 2578), and the results are in line with the results based on the narrower sample used in order to include the UK.

${ }^{3}$ In contrast to some studies including trade unions in the citizen category, we draw on the most common classification in the Nordic literature where citizen groups are defined as those groups representing groups or causes not associated with the economy.

4 To make relationships linear, the variable for staff involved in advocacy was logarithmically transformed.

${ }^{5}$ In Finland and Denmark, there are legal requirements that certain types of groups must be consulted when preparing certain laws. However, only a few laws have these requirements, and they do not specify the means of consultation.

${ }^{6}$ While our data do not permit rigorous comparison with the past, the figures from committee memberships in Finland in the 1970s support this conclusion (Helander \& Johansson 1998). 
Table 1. Importance of different advocacy sites for interest groups in Finland, Denmark and the UK

\begin{tabular}{|c|c|c|c|c|c|c|}
\hline & \multicolumn{6}{|c|}{ 'Important' or 'very important' [to gain political influence] } \\
\hline & \multicolumn{2}{|l|}{ Finland } & \multicolumn{2}{|c|}{ Denmark (ref.) } & \multicolumn{2}{|l|}{ UK } \\
\hline & $\%$ & $\mathrm{~N}$ (total) & $\%$ & $\mathrm{~N}$ (total) & $\%$ & $\mathrm{~N}$ (total \\
\hline \multicolumn{7}{|l|}{ Administration } \\
\hline $\begin{array}{l}\text { Use membership in } \\
\text { boards, councils, or } \\
\text { committees/preparatory } \\
\text { working groups }{ }^{a}\end{array}$ & $80.5^{\star *}$ & 539 & 72.0 & 553 & $59.2^{* * *}$ & 441 \\
\hline Contact public servants & $87.1^{*}$ & 556 & 82.1 & 563 & 82.0 & 439 \\
\hline \multicolumn{7}{|l|}{ Cabinet } \\
\hline Contact ministers & $77.0^{\star \star *}$ & 548 & 87.9 & 556 & 84.9 & 444 \\
\hline \multicolumn{7}{|l|}{ Parliament } \\
\hline $\begin{array}{l}\text { Contact parliamentary } \\
\text { committees }\end{array}$ & $72.1^{\star \star \star}$ & 556 & 83.4 & 561 & $76.4^{\star *}$ & 449 \\
\hline $\begin{array}{l}\text { Contact political parties' } \\
\text { spokespersons/leading } \\
\text { politicians }^{\mathrm{b}}\end{array}$ & $72.5^{\star \star *}$ & 556 & 86.6 & 567 & $62.8^{\star * *}$ & 443 \\
\hline Contact other MPs & 72.0 & 554 & 69.0 & 562 & 72.9 & 442 \\
\hline
\end{tabular}

Note: The significance levels are based on chi-square tests comparing Denmark with the other countries separately. As robustness checks, we also conducted binary logistic regressions (supplementary Table B). The regression results are in line with the results of the chi-square tests, except regarding contacts with parliamentary committees, where the difference between Denmark and the UK is not significant with regression analysis, and regarding contacts with other MPs, which are significantly more important in Finland and UK than in Denmark.

Significance levels: $* \mathrm{p}<0.05, * * \mathrm{p}<0.01, * * * \mathrm{p}<0.001$.

a The wording was slightly different in Finland, where we asked about 'preparatory working groups' instead of 'committees' (komiteat), which has a more limited meaning in the Finnish language. Committees are only very rarely used in Finland currently.

b In Finland, we asked about 'leading politicians' because parties do not have spokespersons. 
Table 2. Linear regression analyses (OLS) predicting interest groups' satisfaction with their access to policymaking in Finland

\begin{tabular}{lll}
\hline & Model 1 & Model 2 \\
\hline Group type (ref. business associations) & & \\
Trade unions & -0.193 & -0.146 \\
& $(0.122)$ & $(0.107)$ \\
Institutional groups & $0.335^{*}$ & $0.224+$ \\
& $(0.151)$ & $(0.133)$ \\
Professional associations & $-0.679^{* * *}$ & $-0.178+$ \\
& $(0.107)$ & $(0.097)$ \\
Identity groups & $-0.662^{* * *}$ & $-0.536^{* * *}$ \\
& $(0.112)$ & $(0.098)$ \\
Leisure groups & $-0.765^{* * *}$ & $-0.279^{*}$ \\
& $(0.121)$ & $(0.109)$ \\
Public interest groups & $-0.445^{* * *}$ & $-0.416^{* * *}$ \\
& $(0.127)$ & $(0.111)$ \\
Staff involved in advocacy (In) & - & $0.916^{* * *}$ \\
Policy influence as goal & & $(0.075)$ \\
Scope of areas & & $0.409^{* * *}$ \\
Constant & - & $(0.047)$ \\
& & -0.004 \\
& & $(0.004)$ \\
& & 0.243 \\
& & $(0.158)$ \\
& & 0.304 \\
& & 1,101 \\
\hline
\end{tabular}

Note: Entries are unstandardized coefficients with standard errors in parentheses. Significance levels: $+\mathrm{p}<0.1, * \mathrm{p}<0.05, * * \mathrm{p}<0.01, * * * \mathrm{p}<0.001$. 
Figure 1. Average privileged position of different kinds of groups in Finland, Denmark and the UK (with $95 \%$ confidence intervals)

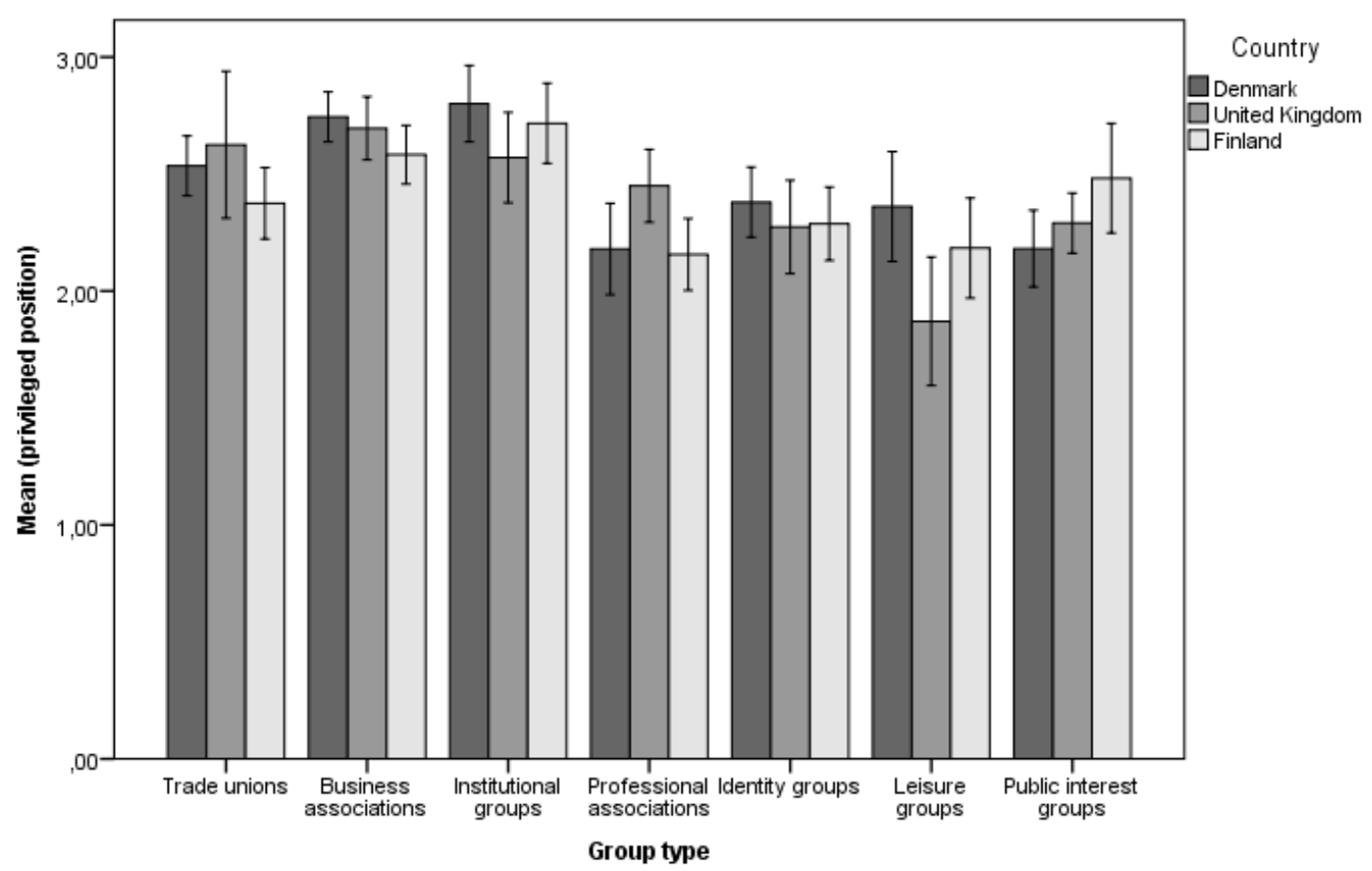


Table 3. Interest groups' contacts with the administrative arena in Finland, Denmark and the UK (percentages)

\begin{tabular}{lllll}
\hline & $\begin{array}{l}\text { Contacts with civil } \\
\text { servants in law- } \\
\text { making (Finland) }\end{array}$ & $\begin{array}{l}\text { Committee seats } \\
(\text { Denmark 2010) }\end{array}$ & $\begin{array}{l}\text { Responses to } \\
\text { consultations } \\
(\text { Denmark 2009/10) }\end{array}$ & $\begin{array}{l}\text { Responses to } \\
\text { consultations } \\
(\text { UK 2008) }\end{array}$ \\
\hline $\begin{array}{l}\text { Business associations } \\
\text { Trade unions }\end{array}$ & 46.3 & 40.9 & 41.0 & 35.6 \\
$\begin{array}{l}\text { Institutional groups } \\
\text { Professional }\end{array}$ & 16.6 & 25.2 & 20.3 & 3.7 \\
$\begin{array}{l}\text { associations } \\
\begin{array}{l}\text { Economic groups } \\
\text { (subtotal) }\end{array}\end{array}$ & 14.5 & 13.7 & 14.9 & 3.8 \\
$\begin{array}{l}\text { Public interest groups } \\
\text { (dentity groups }\end{array}$ & 9.0 & 4.2 & 2.4 & 21.8 \\
$\begin{array}{l}\text { Leisure groups/other } \\
\text { groups }\end{array}$ & 1.5 & 84.0 & 78.6 & 64.9 \\
$\begin{array}{l}\text { Citizen groups } \\
\text { (subtotal) }\end{array}$ & 18.2 & 8.6 & 7.8 & 19.1 \\
$\begin{array}{l}\text { Total \% } \\
\text { N }\end{array}$ & 100 & 4.3 & 9.9 & 13.4 \\
\hline
\end{tabular}

a Surveyed civil servants were asked to identify a recent law preparation process and to name the five extra-governmental organizations with which they interacted most during the process.

b Source: Binderkrantz et al. 2015.

d Source: Binderkrantz et al. 2014.

e Source: Rasmussen 2015. 
Figure 2. Effect of staff size on interest groups' privileged position in policymaking in Finland, Denmark and the UK

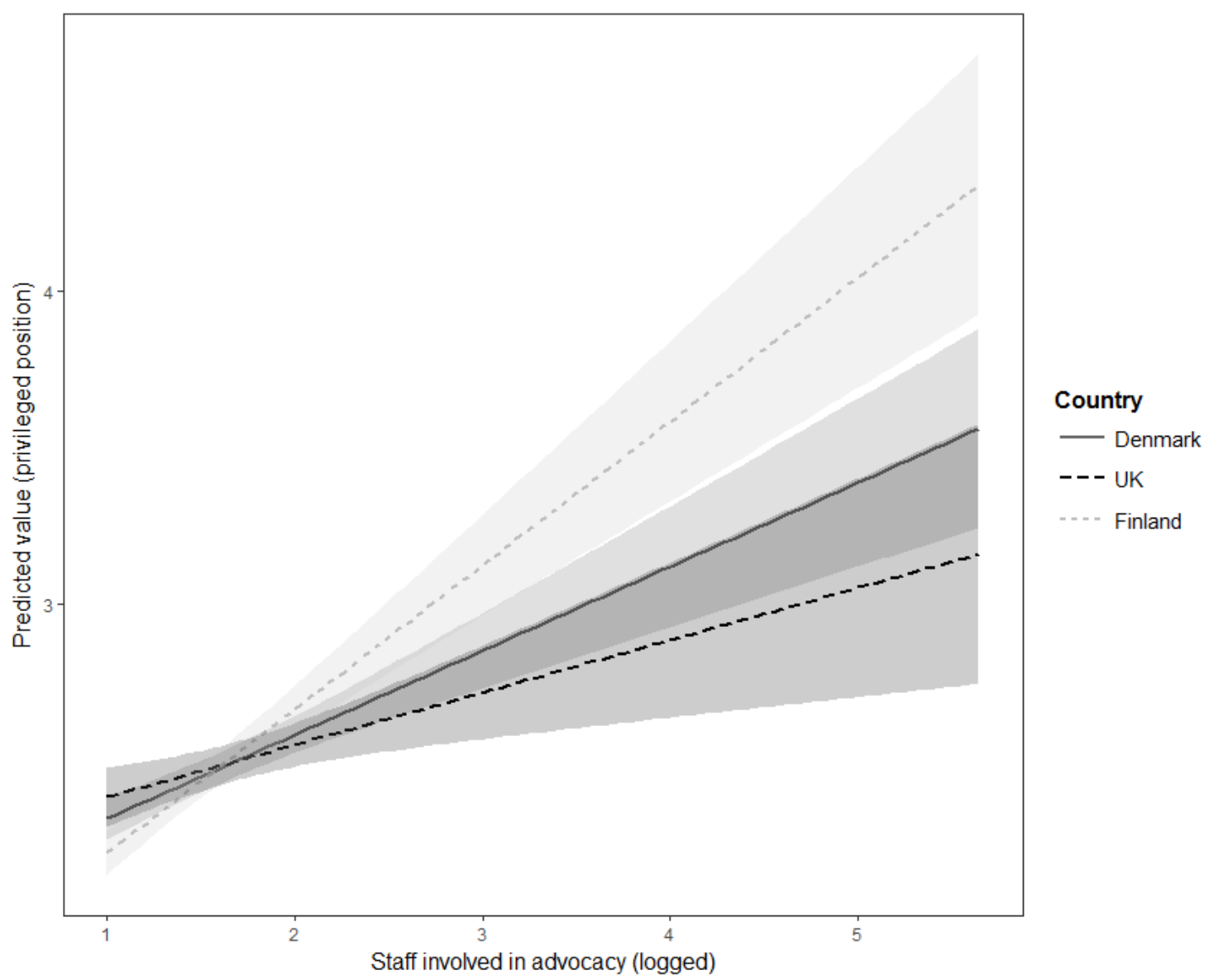

Note: Figure shows the predicted value of privileged position for groups with different staff sizes, based on the linear regression in supplementary Table $\mathrm{E}$ (with $95 \%$ confidence intervals). Other variables are held constant. The minimum of the logged variable for staff is 1 because we used the following formula: $\ln ($ staff +2.718$)$. 